\title{
Dampak Permainan Super Smart Kids Terhadap Kecerdasan Logika-Matematika Anak Usia Dini
}

\section{Masganti1 $^{*}$, Arlina $^{2}$, Widai $^{3}$}

1,2,3 Pendidikan Islam Anak Usia Dini, Universitas Islam Negeri Sumatera Utara, Medan, Indonesia

\section{ART I CLE I N F O}

\section{Article history:}

Received July 08, 2021

Revised July 10, 2021

Accepted October 23, 2021

Available online December 25, 2021

\section{Kata Kunci}

Kecerdasan Logika-Matematika,

Kemampuan Matematis

\section{Keywords:}

Logical-Mathematical Intelligence, Mathematical Ability

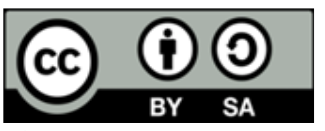

This is an open access article under the CC BY-SA license.

Copyright (C) 2021 by Author. Published by Universitas Pendidikan Ganesha.

\begin{abstract}
A B S T R A K
Kecerdasan logika-matematika sangat penting bagi kehidupan anak. Namun masih ditemukan bahwa 10 dari 18 anak usia dini yang memiliki kecerdasan logika-matematika yang rendah, belum mampu berhitung tanpa bantuan guru, dan mengetahui angka karena hafal lirik lagu urutan angka bukan memahami kuantitas angka yang dimaksud. Oleh karena itu, penelitian ini bertujuan untuk menganalisis dampak permainan super smart kids terhadap kecerdasan logikamatematika anak usia dini.. Penelitian ini berjenis kuantitatif dengan menggunakan desain Quasi Experimentaltipe Non-equivalent Control Group. sampel yaitu 36 orang anak usia 5-6 tahun, yang terdiri dari 18 anak kelompok B1 dan 18 anak kelompok B2. Teknik pengumpulan data pada penelitian ini yaitu observasi terstruktur menggunakan instrumen lembar observasi. Teknik analisis ada yang digunakan yaitu uji-t. Hasil penelitian membuktikan bahwa permainan super smart kids dapat mempengaruhi kecerdasan logika-Matematika anak usia dini hal ini ditunjukkan oleh skor skor thitung sebesar 4,500 lebih tinggi daripada skor tabel yaitu 2,101. Jadi, permainan super smart kids sangat direkomendasikan dalam proses pembelajaran, khususnya untuk meningkatkan kemampuan matematis, berfikir logis, dan kecerdasan logika-matematika anak usia dini.
\end{abstract}

\begin{abstract}
A B S T RA C T
Logical-mathematical intelligence is essential for children's lives. However, it is still found that 10 out of 18 early childhood children who have low logical-mathematical intelligence have not been able to count without the teacher's help and know numbers because memorizing the lyrics of the song sequence of numbers does not understand the quantity of the numbers in question. Therefore, this study aims to analyze the impact of super-smart kids games on logic-mathematical intelligence in early childhood. This research is a quantitative type using a Quasi-Experimental design of the Non-equivalent Control Group type. The sample is 36 children aged 5-6 years, 18 children in group B1 and 18 children in group B2. The data collection technique in this study is structured observation using an observation sheet instrument. The analytical technique used is the t-test. The study results prove that super-smart kids games can affect the logical-mathematical intelligence of early childhood. It is indicated by the t-table score of 4,500, which is higher than the ttable score of 2.101. So, super-smart kids games are highly recommended in the learning process, significantly improving mathematical abilities, logical thinking, and logic-mathematical intelligence for early childhood.
\end{abstract}

\section{PENDAHULUAN}

Pendidikan anak usia dini merupakan pendidikan yang sangat mendasar dan sangat menentukan bagi perkembangan anak dikemudian hari. Hal tersebut karena anak adalah generasi penerus bangsa sehingga kehadirannya dinantikan, pertumbuhan dan perkembangannya diperhatikan, dan pencapaian cita-citanya begitu diharapkan agar dapat menjadi insan yang berguna dalam lingkungan keluarga, lingkungan sekolah, lingkungan masyarakat sekitar maupun Negara secara kompleksitas (Maisarah, 2018). Salah satu bentuk pendidikan anak usia dini yaitu TK yang merupakan lembaga yang memberikan layanan pendidikan bagi anak usia dini pada rentang usia 4-6 tahun. Masa ini merupakan masa emas perkembangan bagi anak karena terjadi peningkatan perkembangan yang luar biasa dan tidak akan terjadi pada periode berikutnya. Para ahli menyebutnya sebagai usia emas perkembangan (golden age) (Al Mubarok \& Amini, 
2020; Kembuan et al., 2019; Rahmi et al., 2020; Sit et al., 2021; Ulfah, 2018). Pada masa ini dikembangkan beberapa aspek yaitu: nilai agama dan moral, sosial-emosional, bahasa, kognitif, dan fisik-motorik melalui pembelajaran di PAUD. Selain aspek perkembangan tersebut, pada PAUD juga memperhatikan kecerdasan majemuk (multiple intelligences). Terdapat sembilan kecerdasan di dalam multiple intelligences, yaitu: verbal-lingustik, logika-matematika, visual-spasial, musikal, kinestetik, interpersonal, intrapersonal, naturalis, dan eksistensial (Attamimi \& Umarella, 2019). Kecerdasan logika-matematika merupakan gabungan dari kemampuan berhitung dan logika sehingga siswa dapat menyelesaikan suatu masalah secara logis (Suhendri, 2011). Salah satu fokus perkembangan PAUD pada aspek kognitif yaitu untuk mengembangkan kemampuan berfikir logis, sistematis, simbolis, dan keterampilan pemecahan masalah melalui kegiatan pengamatan benda-benda konkrit, gambar, maupun simbol angka (Maisarah, 2018; Nur et al., 2020). Keberhasilan kehidupan seseorang dipengaruhi oleh banyak hal, salah satunya adalah kemampuan berfikir dalam mengatasi masalah yang dihadapi (Puspitasari, 2015). Oleh karena itu, anak yang mempunyai kecerdasan logika matematika yang tinggi ditandai dengan kemampuannya untuk berfikir logis, sistematis serta mampu memecahkan masalah sederhana sesuai dengan tahapan kognitifnya.

Teori kognitif Jean Piaget mengemukakan bahwa anak usia 2-6 tahun termasuk ke dalam masa praoperasional. Pada tahap ini anak mulai berpikir dengan jelas. Pada tahapan ini, anak telah menunjukkan aktivitas kognitif dalam menghadapi berbagai hal diluar dirinya. Aktivitas berfikirnya belum mempunyai sistem yang teroganisasikan. Anak sudah dapat memahami realitas di lingkungan dengan menggunakan tanda-tanda dan simbol (Ibda, 2015). Kecerdasan logika-matematika ditandai dengan kepekaan pada polapola logis dan memiliki kemampuan mencerna pola-pola tersebut, termasuk juga numerik serta mampu mengolah alur pemikiran yang panjang (Suminar \& Ashshidiqi, 2020). Seseorang yang memiliki kecerdasan ini cenderung menyukai dan efektif dalam hal menghitung dan menganalisis hitungan, menemukan fungsifungsi dan hubungan, memperkirakan, memprediksi, bereksperimen, mencari jalan keluar yang logis, menemukan adanya pola, induksi dan deduksi, mengorganisasikan/ membuat garis besar, membuat langkah-langkah, bermain permainan yang perlu strategi, berpikir abstrak dan menggunakan simbol abstrak, dan menggunakan algoritma (Attamimi \& Umarella, 2019). Dari uraian di atas terlihat jelas pentingnya kecerdasan logika-matematika bagi kehidupan anak usia dini dan pendidik pada lembaga PAUD diharapkan dapat menstimulasi kecerdasan logika-matematika melalui kegiatan pembelajaran. Namun kenyataan di RA Nurul Kawakib Medan, berdasarkan hasil pengamatan tes awal diperoleh bahwa 10 dari 18 anak orang anak membutuhkan bantuan guru untuk mengerjakan tugas berhitung. Berdasarkan identifikasi, faktor penyebab kurangnya kemampuan anak dalam berhitung karena anak belum mengenal angka secara kuantitas dan konsep. Dalam proses pembelajaran, anak mengetahui angka karena hafal lirik lagu urutan angka, dan memberikan jawaba yang tidak tepat ketika pendidik memberikan kuis mengenai konsep matematika (khususnya berhitung). Hal inilah yang harus diperbaiki dengan permainan yang menstimulasi kecerdasan logika-matematika anak.

Beberapa cara yang dapat digunakan untuk merangsang kecerdasan logika matematika seperti menempelkan poster-poster matematika, mengajarkan pada anak cara menghitung yang menyenangkan dan mudah dilakukan dimana saja, memberikan alat untuk menghitung yang menarik, stimulasi dengan permainan yang mengajarkan teknik membaca logis, tebak-tebakkan, teka-teki, dan sebagainya. Permainan dalam proses pembelajaran juga terbukti mampu menstimulasi perkembangan anak. Bermain merupakan proses mempersiapkan diri, dan mengembangkan berbagai aspek perkembangan dan kecerdasan anak usia dini (Suryani, 2019). Bermain memiliki fungsi bagi anak yaitu: mengembangkan keseimbangan fisik, kognitif, sosial-emosional, bahasa dan komunikasi; menghayati berbagai pengalaman yang diperoleh melalui kehidupan sehari-hari; mengantisipasi peran yang akan dijalankan anak dimasa yang akan datang; menyempurnakan berbagai kemampuan melalui berbagai keterampilan fisik, kognitif, sosial-emosional, bahasa dan komunikasi, serta pembentukan perilaku positif (Musyarofah, 2017). Anak usia 5-6 tahun cenderung menyukai aktivitas berhitung, meyukai permainan yang banyak melibatkan berpikir aktif, seperti catur dan bermain teka-teki (Maulidah \& Santoso, 2012). Oleh karena itu, dianggap bahwa permainan dapat mempengaruhi kecerdasan logika-matematika anak.

Salah satu permainan yang digunakan untuk mempengaruhi kecerdasan logika-matematika anak di RA Nurul Kawakib yaitu permainan super smart kids. Permainan super smart kids merupakan permainan Fun Thinkers, yang mempunyai definisi sebagai alat pembelajaran interaktif untuk menggelitik rasa ingin tahu anak (Mutiah, 2012; Salpina, 2019). Permainan super smart kids ini dapat membantu anak belajar berhitung dari berbagai unsur dengan senang, tidak cepat bosan, tidak cepat lelah. Dalam permainan super smart kids ini anak diajak untuk menghitung banyak objek seperti: titik, angka, penjumlahan serta akan ditingkatkan kemampuan logika matematika anak dengan materi warna. Permainan ini akan menambahkan semangat anak karena dipenuhi objek-objek yang menarik. Dengan demikian, dilakukan penelitian bertujuan untuk menganalisis dampak permainan super smart kids terhadap kecerdasan logikamatematika anak usia dini. 


\section{METODE}

Metode penelitian yang digunakan yaitu penelitian kuantitatif dengan desain Quasi Experimental tipe Non-equivalent Control Group Design. Tipe ini digunakan apabila terdapat dua kelompok sampel yang tidak dipilih secara random, kemudian salah satu kelompok menerapkan sebuah treatment sedangkan kelompok lainnya tidak (Khadijah et al., 2021). Pada penelitian ini digunakan teknik total sampling sehingga jumlah populasi sama seperti jumlah sampel yaitu 36 orang anak usia 5-6 tahun, yang terdiri dari 18 anak kelompok B1 dan 18 anak kelompok B2. Penelitian ini dilaksanakan di RA Nurul Kawakib Medan. Teknik analisis data yang digunakan pada penelitian ini yaitu uji-t sampel related. Teknik pengumpulan data yang dipilih yaitu observasi terstruktur. Pada teknik observasi terstruktur digunakan instrumen berupa lembar observasi dan pedoman penskoran. Kisi-kisi instrumen lembar observasi untuk mengukur kecerdasan logika-matematika disajikan pada Tabel 1.

Tabel 1. Kisi-kisi Instrumen Kecerdasan Logika-Matematika

\begin{tabular}{ll}
\hline Indikator & Deskriptor \\
\hline Kemampuan membilang atau menghubungkan & 1. Menyebutkan lambang bilangan 1-20 \\
lambang dengan bilangan (angka 1-20) & 2. Mencocokkan bilangan dengan lambang bilangan \\
Kemampuan mengenal bentuk geometri dan & 3. Mengklasifikasikan benda berdasarkan warna \\
warna & 4. Mengklasifikasikan benda berdasarkan bentuk \\
Kemampuan berhitung & 5. Menjumlahkan angka satuan dengan satuan \\
& menggunakan simbol yang tepat $(1+2=\ldots)$ \\
& 6. Menjumlahkan angka puluhan dengan satuan \\
& menggunakan simbol yang tepat $(14+2=\ldots)$ \\
\hline
\end{tabular}

Sumber: (Agustin, 2013; Maisarah, 2018; Mufarizuddin, 2017; Sumardi et al., 2017).

\section{HASIL DAN PEMBAHASAN}

\section{Hasil}

Hasil penelitian diperoleh rata-rata skor pretes kecerdasan logika-matematika anak sebelum diterapkan treatment pada kelas eksperimen sebesar 14,4 relatif sama dengan kelas kontrol yaitu 14,8. Setelah diterapkan permainan super smart kids di kelas eksperimen mengalami peningkatan rata-rata skor postes kecerdasan logika-matematika menjadi 18,0 lebih tinggi dari kelas kontrol yang menerapkan penugasan tanpa permainan yaitu 16,5. Data menggambarkan bahwa permainan super smart kids (kelas eksperimen) maupun penugasan tanpa permainan (kelas kontrol) memberikan pengaruh terhadap skor kecerdasan logika-matematika anak kelompok B di RA Nurul Kawakib Medan, namun di kelas eksperimen mempunyai skor postes yang lebih tinggi daripada kelas kontrol. Skor postes tertinggi di kelas eksperimen dan kontrol sama-sama berada pada interval 22-23, sedangkan skor postes terendah di kelas eksperimen berada pada interval 14-15 (sebanyak 2 orang) lebih tinggi 1 tingkat dari kelas kontrol yaitu 12-13 (sebanyak 3 orang). Data terbanyak (modus) di kelas eksperimen berada pada interval 18-19 (sebanyak 7 orang) lebih tinggi 2 tingkat dari kelas kontrol yaitu 14-15 (sebanyak 5 orang). Dari sebaran data juga membuktikan bahwa terdapat pengaruh dari permainan super smart kids terhadap kecerdasan logikamatematika anak kelompok B di RA Nurul Kawakib Medan. Selanjutnya data postes diuji hipotesis untuk mengetahui pengaruh yang signifikan. Uji hipotesis yang digunakan adalah uji-t karena asumsi dasarnya telah terpenuhi, yaitu data berdistribusi normal dan bervarians homogen. Hasil uji normalitas menunjukkan bahwa skor Lhitung sebesar 0,165 dan 0,136 lebih rendah daripada skor Ltabel yaitu 0,200 sehingga dapat dikatakan bahwa data berasal dari sebaran data normal. Dari uji homogenitas diperoleh skor Fhitung sebesar 1,980 lebih rendah daripada skor $F_{\text {tabel }}$ yaitu 2,217 sehingga data berasal dari kelompok data homogen. Jadi, data berdistribusi normal dan bervarians homogen sehingga uji hipotesis dapat menggunakan uji-t. Hasil uji-t menunjukkan bahwa skor thitung sebesar 4,500 lebih tinggi daripada skor tabel yaitu 2,101 sehingga terdapat pengaruh yang signifikan dari permainan super smart kids terhadap kecerdasan logika-matematika anak kelompok B di RA Nurul Kawakib Medan. Setelah melakukan pengujian di atas, ditemukannya suatu temuan bahwa kecerdasan logika matematika anak di RA Nurul Kawakib mengalami peningkatan pada jumlah keseluruhan dari pre-tes ke postes baik kelas yang menggunakan permainan super smart kids maupun menggunakan metode penugasan tanpa permainan. Kelas kontrol yang tidak menggunakan permainan super smart kids juga mengalami pengaruh dari penugasan itu sendiri. Kelas eksperimen yang menggunakan permainan super smart kids memperoleh skor yang lebih tinggi dari kelas kontrol. Contoh Permainan Super smart kids ditunjukkan pada Gambar 1 dan Gambar 2. Pada Gambar 1, anak mengelompokkan gambar yang sesuai dan dibalik papan gambar tersebut tersedia angka. Jika anak berhasil mengelompokkan gambar maka angka di belakangnya akan terurut. Pada Gambar 2, anak memindahkan setiap angka di halaman kanan yang sesuai dengan gambar yang disediakan pada halaman 
kiri. Dengan permainan ini, maka anak akan menghitung benda yang ada pada setiap kolom dan mencocokkan jumlah benda tersebut dengan angka yang sesuai. Dengan begitu, maka akan akan mengetahui kuantitas atau jumlah nyata dari setiap angka, bukan menghafal urutan.

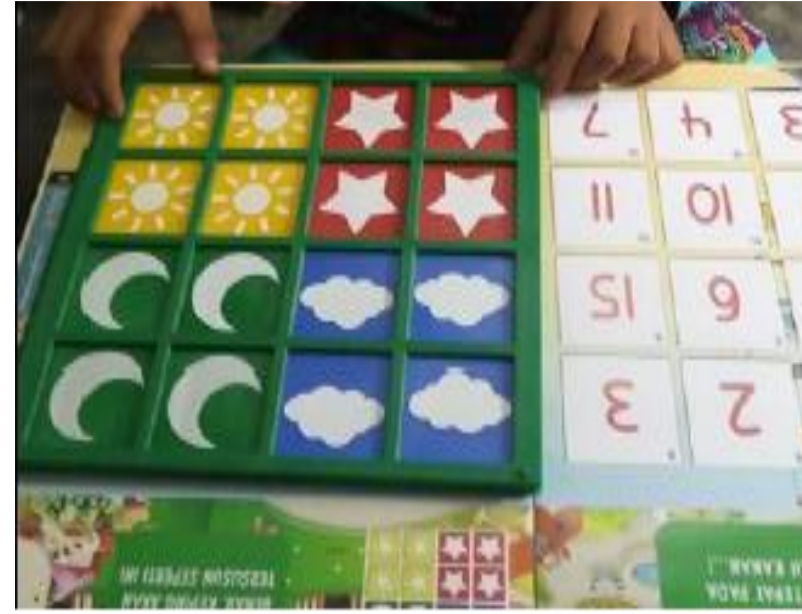

Gambar 1. Contoh Permainan Super smart kids

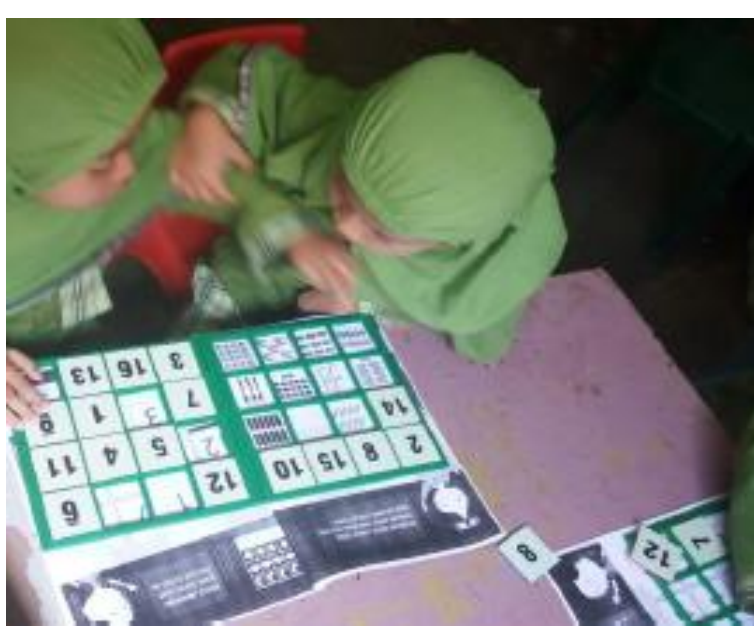

Gambar 2. Contoh Permainan Super smart kids

\section{Pembahasan}

Dari hasil penelitian juga ditemukan bahwa anak di kelas eksperimen yang menggunakan permainan super smart kids mempunyai semangat belajar, rasa ingin tahu yang tinggi sehingga tujuan pembelajaran tercapai, bahkan sebagian anak dapat membantu temannya yang mengalami kesulitan ketika menemukan jawaban. Permainan super smart kids merupakan permainan Fun Thinkers, yang mempunyai definisi sebagai alat pembelajaran interaktif untuk menggelitik rasa ingin tahu anak. Penelitian ini menggunakan permainan super smart kids berbentuk buku dengan materi menghitung angka sehingga cocok untuk mempengaruhi kecerdasan logika-matematika anak. Anak usia dini mempunyai kecenderungan sifat bosan dan lelah (Mutiah, 2012). Jika anak sudah menemukan kemudahan dalam bermain, maka karakter cepat bosan dan cepat lelah akan berubah menjadi semangat untuk mengulangi terus permainannya sehingga mereka mampu bermain sendiri. Target permainan super smart kids adalah anak-anak bisa bermain dan menjawab pertanyaan secara cepat dan tepat (Team, 2016). Dengan demikian, stimulasi otak agar bisa berfikir secara sistematis, dapat diperoleh anak-anak dalam masa pertumbuhannya. Hasil penelitian juga didukung oleh beberapa penelitian relevan yang membuktikan bahwa kecerdasan logika matematika sangat penting sehingga banyak yang meneliti dan permainan juga memberikan pengaruh terhadap kecerdasan tersebut. Beberapa penelitian tersebut membuktikan bahwa: keberhasilan dalam menstimulasi kecerdasan logika matematika tergantung pada alat permainan edukatif yang digunakan (Ezkanandyta et al., 2019). Kecerdasan logika matematika anak dapat dipengaruhi oleh permainan ular tangga (Pahwani, 2018). Model teams games tournaments melalui media fun thinkers menjadi model pembelajaran inovatif, mampu meningkatakan aktivitas dan prestasi belajar kognitif (Widyaningsih, 2014). Penerapan permainan kartu angka dapat meningkatkan logika matematika anak usia 5-6 tahun di TK Widya Bhakti (Noermayanti \& Hasibuan, 2017).

Penerapan permainan di dalam proses pembelajaran mempengaruhi kecerdasan anak, bahkan permainan mempunyai banyak manfaat lain. Manfaat bermain dapat mengembangkan aspek moral, motorik, kognitif, bahasa, serta perkembangan sosial anak. Dengan bermain, anak akan lebih mudah menerima konsep (pengetahuan, ingatan, kreativitas, daya pikir, daya nalar). Contoh sederhana yaitu ketika bermain bola dan anak memahami warna bola, ukuran bentuk, dll (Rohmah, 2016). Bermain adalah salah satu cara terpenting di mana anak-anak kecil memperoleh pengetahuan dan keterampilan yang penting. Tahun pendidikan pra-sekolah (atau pra-sekolah dasar) jatuh di tengah-tengah periode masa kanak-kanak awal dan meletakkan dasar untuk sukses. di sekolah dan di luar. Meskipun ringkasan ini difokuskan pada tahun-tahun pra-sekolah dasar, kami mencatat bahwa belajar melalui permainan relevan sepanjang seluruh periode anak usia dini dan seterusnya (Jung \& Hasan, 2016; Kaul et al., 2017; Rao, 2017).

Kegiatan bermain dapat memberikan manfaat terhadap kecerdasan logika-matematika karena daya pikir dan nalar, serta kemampuan memahami warna, bentuk dan ukuran termasuk ke dalam kecerdasan logika-matematika. Bermain adalah komponen penting dari perkembangan anak kecil, memiliki manfaat terkenal yang menjangkau semua aspek pengembangan kognitif, fisik, sosial, dan emosional (Gleave \& Cole-Hamilton, 2012). Bermain memiliki peran unik dalam belajar dan memberikan kesempatan bagi anak-anak untuk menolak tujuan dan tujuan yang ditentukan sebelumnya, belajar untuk mentolerir 
ketidakpastian, dan menyambut keragaman (Nitecki \& Chung, 2016). Ketika anak-anak bermain, mereka terlibat dalam penemuan tentang alam, dunia nyata, yang merupakan dasar untuk belajar di masa kanakkanak. Ketika anak-anak bermain, mereka dapat mencoba keterampilan sosial baru (misalnya, berbagi mainan, menyetujui cara bekerja sama dengan materi) dan mereka sering melakukan beberapa tugas kognitif yang menantang (seperti mencari tahu cara membuat bangunan) dengan blok yang lebih kecil ketika yang lebih besar tidak tersedia). Dengan demikian, pengetahuan anak berkembang seiring proses bermain yang diikuti dan permainan di dalam pembelajaran menganut pendekatan konstruktivisme (Gunduz \& Hursen, 2015). Anak-anak membutuhkan banyak latihan dengan benda padat untuk memahami konsep abstrak. Sebagai contoh, dengan bermain dengan blok geometris mereka memahami konsep bahwa dua kotak dapat membentuk persegi panjang dan dua segitiga dapat membentuk persegi. Dari menari pola seperti langkah maju, mundur, berputar, dan ulangi, mereka mulai memahami fitur pola yang merupakan dasar untuk matematika. Permainan pura-pura atau 'simbolis' (seperti bermain rumah atau pasar) sangat bermanfaat: dalam permainan seperti itu, anak-anak mengekspresikan ide, pikiran dan perasaan mereka, belajar bagaimana mengendalikan emosi mereka, berinteraksi dengan orang lain, menyelesaikan konflik dan mendapatkan rasa kompetensi. Proses pembelajarn yang seperti ini tentunya memberikan dampak yang positif terhadap kecerdasan logika matematika.

Kecerdasan logika matematika yaitu kemampuan untuk mengenal warna dan bentuk secara efektif guna meningkatkan keterampilan mengelolah angka serta kemahiran mengguakan logika atau akal sehat (Mufarizuddin, 2017). Indikator kemampuan berpikir logis dan simbolik anak usia 5-6 tahun yaitu: mengklasifikasi benda berdasarkan warna, bentuk dan ukuran; mengurutkan benda; menyebutkan lambang bilangan, dan mencocokkan bilangan dengan lambang bilangan (Sumardi et al., 2017). Ciri-ciri anak yang mempunyai kecerdasan logika-matematika yang tinggi yaitu: memiliki kemampuan dalam mengolah angka atau kemahiran menggunakan logika, tertarik memanipulasi lingkungan serta cenderung suka menerapkan strategi coba-ralat, memiliki rasa ingin tahu yang besar terhadap suatu peristiwa atau pengalaman yang dialami, dan suka menyusun permainan yang sifatnya kategori dan hierarki (Agustin, 2013). Teori kognitif Jean Piaget mengemukakan bahwa anak usia 2-6 tahun sudah dapat memahami realitas di lingkungan dengan menggunakan tanda-tanda dan simbol (Ibda, 2015). Anak usia 5-6 tahun juga cenderung menyukai aktivitas berhitung, meyukai permainan yang banyak melibatkan berpikir aktif, seperti catur dan bermain teka-teki (Maulidah \& Santoso, 2012). Dengan demikian, penerapan permainan dianggap dapat mempengaruhi kecerdasan logika-matematika, serta perkembangan dan kecerdasan lain. Dengan permainan super smart kids ini, bukan hanya mengembangkan kecerdasan logika-matematika anak tetapi juga memperhatikan aspek perkembangan lain seperti perkembangan kognitif dan sosial emosional karena menambah rasa ingin tahu anak dan menciptakan rasa senang dalam belajar. Namun dampak negatif akan terjadi jika guru tidak membimbing anak ketika menggunakan permainan super smart kids, akan terjadi perkelahian antara siswa yang satu dengan lainnya jika tidak dibiasakan untuk sabar menunggu antrian. Hal ini membuktikan bahwa setiap permainan di dalam proses pembelajaran memberikan dampak positif juga negatif, dan guru menjadi fasilitator seharusnya mengoptimalkan dampak positif dan meminimalisir dampak negatif yang timbul terhadap perkembangan dan kecerdasan anak usia dini. Selain dapat berpengaruh terhdap kecerdasan logika-matematika permaian super smart kids juga dapat menumbuhkan perkembangan sosial emosional.

Perkembangan sosio-emosional prasekolah adalah salah satu aspek terpenting dari perkembangan prasekolah (Khoiruddin, 2018; Rahmawati \& Latifah, 2020). Proses sosial emosional dapat muncul sebagai akibat adanya interaksi sosial yang dilakukan oleh individu, kelompok maupun masyarakat (Anggraini \& Kuswanto, 2019). Perkembangan sosial emosional mencakup keterampilan yang mendukung kesiapan dan persiapan sekolah anak untuk belajar seumur hidup seperti percaya diri, rasa ingin tahu, intensionalitas, pengendalian diri, keterkaitan, komunikasi, dan kerja sama (Waltz, 2013). Beberapa keterampilan tersebut juga dipupuk dalam diri anak melalui permainan super smart kids, sehingga penelitian ini bukan hanya fokus pada objek yang diteliti (kecerdasan logika-matematika) tetapi juga mengembangkan potensi anak secara utuh dan terintegrasi. Salah satunya adalah dengan mengembangkan sosial emosional anak usia dini agar siap untuk belajar ke tahapan selanjutnya maupun belajar sepanjang hayat. Kompetensi sosial dan emosional memainkan peran penting dalam mempersiapkan anak untuk terlibat tugas-tugas kognitif (Perry et al., 2011). Anak-anak yang tidak memiliki keterampilan sosial-emosional yang kuat sering terlibat dalam perilaku yang menantang seperti agresi, penolakan, amukan, dan perusakan properti dan sering diidentifikasi oleh guru sebagai "tidak siap untuk belajar".

Manfaat dari penerapan permainan super smart kids adalah untuk membangun koordinasi dan konsentrasi anak dalam menyelesaikan masalah, meningkatkan skill pada ilmu matematika, melatih kemampuan berpikir, dan belajar menyenangkan (Team, 2016). Selain itu, permainan ini juga melatih keseimbangan otak kanan dan kiri anak. Dari aspek tujuan pembuatan permainan ini maka dapat disimpulkan bahwa permainan super smart kids sangat baik dan cocok untuk meningkatkan logika berpikir 
dan kemampuan matematis anak usia dini, sehingga manfaat tersebut mendukung hasil pada penelitian ini yang membuktikan permaian super smart kids memberikan pengaruh yang signifikan terhadap logikamatematika anak usia dini, khusunya anak usia kelompok B di RA Nurul Kawakib Medan. Dari penelitian ini terdapat beberapa keterbatasan yang ditemukan, yaitu: jumlah papan permainan super smart kids yang tidak sesuai dengan jumlah siswa sehingga dapat menimbulkan perkelahian pada anak yang tidak sabar menunggu giliran jika guru tidak dapat menguasai kelas dengan baik, alokasi waktu penelitian yang terbatas sehingga penggunaan permainan super smart kids tidak seoptimal mungkin, dan alat ukur yang tidak divalidasi kepada tim ahli kecerdasan atau spesialis neurologi sehingga bisa jadi hasil ukur kecerdasan logika-matematika anak pada penelitian ini belum menggambarkan kecerdasan yang sebenarnya. Dari keterbatasan tersebut maka diberikan saran perbaikan untuk peneliti lainnya yang mungkin membahas objek penelitian yang sama (super smart kids, atau kecerdasan logika-matematika), yakni: peneliti menyediakan papan super smart kids dengan jumlah yang sesuai dengan subjek penelitian sehingga tidak menimbulkan hal-hal yang merugikan seperti perkelahian, peneliti atau guru diharapkan dapat menyediakan waktu yang cukup agar penggunaan permainan super smart kids lebih efektif dan memberikan pengaruh yang kompleks terhadap beberapa perkembangan dan kecerdasan, dan diharapkan kepada peneliti untuk menggunakan instrumen yang divalidasi langsung oleh dokter spesial neurologi atau psikolog anak sehingga diperoleh data kecerdasan yang lebih akurat. Namun keterbatasan penelitian yang ditemukan tidak begitu fatal karena penelitian ini memberikan banyak manfaat bagi anak. Penelitian ini bukan hanya menjawab pertanyaan penelitian yakni: terdapat pengaruh permainan super smart kids terhadap kecerdasan logika-matematika, tetapi juga memberikan pengaruh terhadap berbagai perkembangan dan kecerdasan anak, sehingga penelitian ini membantu guru untuk mencapai tujuan pembelajaran. Dengan demikian, penelitian ini memberikan rekomendasi kepada pihak lembaga PAUD atau pemerhati pendidikan untuk menyediakan permainan super smart kids dan mengoptimalkan manfaatnnya.

\section{SIMPULAN}

Permainan super smart kids digunakan dengan cara memindahkan setiap angka pada halaman kanan papan permainan agar sesuai dengan gambar yang disediakan pada halaman kiri. Dari hasil penelitian terlihat bahwa penggunaan permainan ini dapat melatih kemampuan pemahanan anak mengenai kuantitas angka 1-20, bukan menghafal urutan angka karena lirik lagu ataupun karena bantuan jari. Selain itu, penggunaan permainan ini juga melatih kemampuan pemecahan masalah, berfikir logis, dan berdaya nalar tinggi untuk memahami cara permainannya. Anak menggunakan jarinya untuk memindahkan angka ataupun gambar agar keduanya sesuai, sehingga permainan ini juga melatih kemampuan motorik halus dan kecerdasan kinestetik anak. Dari gambar yang disajikan terlihat bahwa penggunaan permainan ini juga meningkatkan rasa ingin tahu, semangat dan senang belajar matematika, serta melatih kesabaran anak untuk mengantri.

\section{DAFTAR RUJUKAN}

Agustin, M. (2013). Mengenali dan Mengembangkan Potensi Kecerdasan Jamak Anak Sejak Dini Sebagai Tonggak Awal Melahirkan Generasi Emas. Cakrawala Dini: Jurnal Pendidikan Anak Usia Dini, 4(2), 113-122. https://doi.org/10.17509/cd.v4i2.10390.

Al Mubarok, A. A. S. A., \& Amini. (2020). Kemampuan Kognitif dalam Mengurutkan Angka melalui Metode Bermain Puzzle Angka. Jurnal Obsesi: Jurnal Pendidikan Anak Usia Dini, 4(1), 77-89. https://doi.org/10.31004/obsesi.v4i1.221.

Anggraini, W., \& Kuswanto, C. W. (2019). Teknik Ceklist Sebagai Asesmen Perkembangan Sosial Emosional di RA. Al-Athfaal: Jurnal Ilmiah Pendidikan Anak Usia Dini, 2(2), 61-70. https://doi.org/10.24042/ajipaud.v2i2.5248.

Attamimi, M. A., \& Umarella, S. (2019). Implementation of The Theory Multiple Intelligences in Improve Competence of Learners on The Subjects of Islamic Religious Education in SMP Negeri 14 Ambon. Al-Iltizam, 4(1), 73-103. https://doi.org/10.33477/alt.v4i1.817.

Ezkanandyta, N., Rachmawati, Y., \& Mariyana, R. (2019). Efektivitas Penggunaan Busy Book Terhadap Kecerdasan Logika Matematika Anak Usia Dini. Edukids: Jurnal Pertumbuhan, Perkembangan Dan Pendidikan Anak Usia Dini, 16(1). https://doi.org/10.17509/edukid.v16i1.20874.

Gleave, J., \& Cole-Hamilton, I. (2012). A world without play: A literature review on the effects of a lack of play on children's lives.

Gunduz, N., \& Hursen, C. (2015). Constructivism in Teaching and Learning: Content Analysis Evaluation. Procedia - Social and Behavioral Sciences, 191, 526-533. https://doi.org/10.1016/j.sbspro.2015.04.640. 
Ibda, F. (2015). Perkembangan Kognitif : Teori Jean Piaget. Intelektualita, 3(1), 27-38.

Jung, H., \& Hasan, A. (2016). The impact of early childhood education on early achievement gaps in Indonesia. Journal of Development Effectiveness, 8(2), 216-233. https://doi.org/10.1080/19439342.2015.1088054.

Kaul, V., Bhattacharjea, S., Chaudhary, A. B., Ramanujan, P., Banerji, M., \& Nanda, M. (2017). The India Early Childhood Education Impact Study. New Delhi: UNICEF.

Kembuan, O., Suwaryaningrat, E., \& Liow, M. C. N. (2019). Perancangan dan Implementasi Aplikasi Permainan Edukatif Bagi Siswa PAUD. Cakrawala Dini: Jurnal Pendidikan Anak Usia Dini, 10(2), 151-155. https://doi.org/10.17509/cd.v10i2.18705.

Khadijah, Arlina, Hardianti, R. W., \& Maisarah. (2021). Model Pembelajaran Bank Street dan Sentra, serta Pengaruhnya terhadap Sosial Emosional Anak. Jurnal Obsesi: Jurnal Pendidikan Anak Usia Dini, 5(2), 1960-1972. https://doi.org/10.31004/obsesi.v5i2.1054.

Khoiruddin, M. A. (2018). Perkembangan Anak Ditinjau dari Kemampuan Sosial Emosional. Tribakti: Jurnal Pemikiran Keislaman, 29(2), 425-438. https://doi.org/10.33367/tribakti.v29i2.624.

Maisarah. (2018). Matematika dan Sains Anak Usia Dini. Medan: Akasha Sakti.

Maulidah, N., \& Santoso, A. (2012). Permainan Konstruktif untuk Meningkatkan Kemampuan Multiple Intelligence (Visual-Spasial dan Interpersonal). Bimbingan Dan Konseling Islam, 2(1). https://doi.org/10.29080\%2Fjbki.v2i1.20.

Mufarizuddin. (2017). Peningkatan Kecerdasaan Logika Matematika Anak melalui Bermain Kartu Angka Kelompok B di TK Pembina Bangkinang Kota. Jurnal Obsesi: Jurnal Pendidikan Anak Usia Dini, 1(1), 62-71. https://doi.org/10.31004/obsesi.v1i1.32.

Musyarofah. (2017). Pengembangan Aspek Sosial Anak Usia Dini di Taman Kanak-Kanak ABA IV Mangli Jember Tahun 2016. Inject: Interdisciplinary Journal of Communication, 2(1), 99-122. https://doi.org/10.18326/inject.v2i1.99-122.

Mutiah, D. (2012). Psikologi Bermain Anak Usia Dini. Jakarta: Kencana Prenada Media Group.

Nitecki, E., \& Chung, M. . (2016). Play as Place: a Safe Space for Young Children to Learn about the World. International Journal of Early Childhood Environmental Education, 4(1), 26-32. https://eric.ed.gov/?id=EJ1120144.

Noermayanti, S., \& Hasibuan, R. (2017). Peningkatan Kemampuan Mengenal Konsep Bilangan 1-5 Melalui Permainan Memancing Pada Anak Usia 3-4 Tahun di KB Tunas Bangsa Kedungturi Gudo Jombang. Jurnal PAUD TERATAI, 6(3), 1-5. https://core.ac.uk/download/pdf/230643844.pdf.

Nur, L., Hafina, A., \& Rusmana, N. (2020). Kemampuan Kognitif Anak Usia Dini dalam Pembelajaran Akuatik. Scholaria: Jurnal Pendidikan Dan Kebudayaan, 10(1), 42-50. https://doi.org/10.24246/j.js.2020.v10.i1.p42-50.

Pahwani, D. (2018). Pengaruh Permainan Ular Tangga Terhadap Kecerdasan Logika Matematika Anak Usia 4-5 Tahun di TK Anak Bangsa Mandiri Kecamatan Labuhan Deli Serdang T.A. 2017/2018. Jurnal Usia Dini, 4(1), 1-8. http://digilib.unimed.ac.id/30958/.

Perry, D. F., Holland, C., Darling-Kuria, N., \& Nadiv, S. (2011). Challenging behavior and expulsion from child care: The role of mental health consultation. Zero to Three Journal, 2. https://eric.ed.gov/?id=EJ961213.

Puspitasari, E. (2015). Pemetaan Kreativitas Anak Usia 4-6 Tahun Di Tk Laboratorium PG-PAUD Universitas Riau. Educhild. http://dx.doi.org/10.33578/jpsbe.v4i1.2802.

Rahmawati, M., \& Latifah, M. (2020). Penggunaan Gawai, Interaksi Ibu-Anak, Dan Perkembangan SosialEmosional Anak Prasekolah. Jur. Ilm. Kel. \& Kons., 13(1), 75-86. https://doi.org/10.24156/jikk.2020.13.1.75.

Rahmi, P., Mawaddah, Fajriah, H., \& Maisarah. (2020). Penerapan Alat Permainan Edukatif Tangram untuk meningkatkan Kreativitas Anak dalam Mengenal Bentuk Geometri di TKN Pembina Lawe Alas. Jurnal Raudhah, 8(1), 81-91. https://doi.org/10.30829/raudhah.v8i1.588.

Rao, N. (2017). Effectiveness of early childhood interventions in promoting cognitive development in developing countries: A systematic review and meta-analysis. HK J Paediatr, 22(1), 14-25. http://www.hkjpaed.org/details.asp?id=1103\&show=1234.

Rohmah, N. (2016). Bermain dan Pemanfaatannya dalam Perkembangan Anak Usia Dini. Tarbawi : Jurnal Pendidikan Islam, 13(2), 27-35.

Salpina. (2019). Implementasi Permainan Super Smart Kids untuk Meningkatkan Kecerdasan Logika Matematika Anak Usia Dini di Masa Pandemi Covid-19. J-SANAK: Jurnal Kajian Anak, 2(1), 14-22. https://doi.org/10.24127/j-sanak.v2i01.366.

Sit, M., Budianti, Y., \& Muliyani, R. (2021). The Application of Number Fishing Game to Improve Basic Mathematics Ability. AXIOM: Jurnal Pendidikan \& Matematika, 10(1), 85-96. https://doi.org/10.30821/axiom.v10i1.8886. 
Suhendri, H. (2011). Pengaruh Kecerdasan Matematis-Logis dan Kemandirian Belajar Terhadap Hasil Belajar Matematika. Jurnal Formatif, 1(1), 29-39. https://doi.org/10.30998/formatif.v1i1.61.

Sumardi, Nur, L., \& Sa'diyyah, H. H. (2017). Kemampuan Matematika Anak Usia 5-6 Tahun di Kober AlHidayah Kecamatan Cikoneng Kabupaten Ciamis. Jurnal PAUD Agapedia, 1(1), 106-117. https://doi.org/10.17509/jpa.v1i1.7164.

Suminar, A., \& Ashshidiqi, A. (2020). Mengembangkan Kecerdasan Logika Matematika dengan Menggunakan Media Realia pada Anak Usia 5-6 Tahun di TK Negeri Pembina. Jurnal Jendela Bunda, 7(2), 25-26. https://e-journal.umc.ac.id/index.php/JJB/article/download/1345/875.

Suryani, N. A. (2019). Kemampuan Sosial Emosional Anak Melalui Permainan Raba-Raba Pada PAUD Kelompok A. Jurnal Ilmiah Potensia, 4(2), 141-150. https://doi.org/10.33369/jip.4.2.141-150.

Team, K. P. (2016). Super Smart Kids, Anakku cerdas dan kreatif (Menghitung Angka). Tangerang: Katahati.

Ulfah, M. (2018). Program Parenting Di Taman Kanak-Kanak Se-Kecamatan Bantul. Jurnal Pendidikan Guru PAUD S-1, 7(1).

Waltz, M. (2013). The importance of social and emotional development in young children.

Widyaningsih, S. Y. (2014). Upaya Meningkatkan Aktivitas Dan Prestasi Belajar Reaksi Redoks Melalui Model Teams Games Tournaments (TGT) Media Fun Thinkers. Implementasi Pendekatan Saintifik Dan Karakter Dalam Penelitian Dan Pembelajaran Sains Menyongsong Generasi Emas Indonesia. https://jurnal.fkip.uns.ac.id/index.php/snps/article/view/5055. 